\title{
Major Outer Membrane Proteins of Escherichia coli Strains of Human Origin
}

\author{
By NICO OVERBEEKE* AND BEN LUGTENBERG \\ Institute for Molecular Biology and Department of Molecular Cell Biology, State University, \\ Transitorium 3, Padualaan 8, $3584 \mathrm{CH}$ Utrecht, The Netherlands
}

(Received 23 April 1980)

The major outer membrane protein patterns of 45 Escherichia coli strains of human origin were compared with that of $E$. coli $\mathrm{K} 12$ by sodium dodecyl sulphate-polyacrylamide gel electrophoresis. Preparations of the former strains contained between two and five major bands in the molecular weight range between 30000 and 42000 . The patterns were very heterogeneous with respect to the numbers and electrophoretic mobilities of the major outer membrane protein bands. In all cases the fastest moving band was characterized as a protein similar to the $\operatorname{omp} A$ protein of strain $\mathrm{K} 12$ as it was partially degraded by trypsin and reacted specifically with antiserum against the purified $o m p A$ protein in a gel immuno-radioassay. All the other major outer membrane proteins are related to the ompC and $o m p F$ proteins (the porins) of strain $\mathrm{K} 12$ as they were peptidoglycan-associated and reacted with antisera against the purified $o m p C$ and/or $o m p F$ proteins.

\section{INTRODUCTION}

The cell envelope of the Enterobacteriaceae consists of three layers: a cytoplasmic membrane, a peptidoglycan layer and, covalently attached to it, an outer membrane (DiRienzo et al., 1978). Analysis of the outer membrane protein pattern with sodium dodecyl sulphate (SDS)-polyacrylamide gel electrophoresis revealed several so-called 'major' proteins (Ames et al., 1974; Lugtenberg et al., 1975). As the relative amounts of several of these proteins are dependent on the growth conditions (Van Alphen \& Lugtenberg, 1977; Braun et al., 1976; Braun \& Krieger-Brauer, 1977; Lugtenberg et al., 1976; Overbeeke \& Lugtenberg, 1980), this term can be misleading. The outer membrane protein pattern of Escherichia coli $\mathrm{K} 12$ is characteristic in that usually three major bands are observed in the molecular weight range between 30000 and 42000 . The nomenclature of these proteins, designated $\mathrm{b}, \mathrm{c}$ and $\mathrm{d}$ in our laboratory (Lugtenberg et al., 1975), was different in other laboratories (Bassford et al., 1977; Henning \& Haller, 1975; Uemura \& Mizushima, 1975). Recently, a new nomenclature has been agreed in which the proteins are called after their structural genes (Reeves, 1979), i.e. ompF, ompC and $o m p A$, respectively, for the proteins $\mathrm{b}, \mathrm{c}$ and $\mathrm{d}$.

The $o m p A$ protein, which plays a role in acceptor cells in F-pilus-mediated conjugation (Van Alphen et al., 1977; Skurray et al., 1974), is partially degraded when cell envelope preparations are incubated with trypsin, resulting in a major degradation product with a molecular weight of about 18000 (Henning et al., 1973). The ompF and ompC proteins form tight complexes with peptidoglycan which resist incubations in $2 \%$ SDS at $60^{\circ} \mathrm{C}$ (Lugtenberg et al., 1976; Rosenbusch, 1974). The latter proteins are involved in the formation of hydrophilic pores through which nutrients and other solutes with a molecular weight of up to about 700 can pass the outer membrane (Van Alphen et al., 1978a, b; 
Bavoil et al., 1977; Lutkenhaus, 1977; Nakae, 1976); they are therefore called porins (Nakae, 1976). There are considerable differences between these two pore proteins with respect to the patterns of their cyanogen bromide and proteolytic fragments (Ichihara \& Mizushima, 1978; Verhoef et al., 1979), but their total amino acid composition and their amino termini are very similar (Ichihara \& Mizushima, 1978; Verhoef et al., 1979; Henning et al., 1977). Immunological studies with antisera raised against the purified proteins showed an antigenic relationship between the $o m p F$ protein and the $o m p C$ protein, while antiserum raised against the $\operatorname{omp} A$ protein only reacted with the homologous protein (Overbeeke et al., 1980).

As most studies of the outer membrane proteins of $E$. coli have been carried out with strain $\mathrm{K} 12$, very little is known about the outer membrane proteins of other $E$. coli strains. Because we were interested to know whether the situation in other strains of human origin resembles that known for strain $\mathrm{K} 12$, we compared several biochemical and immunological properties of the outer membrane proteins of strain $\mathrm{K} 12$ with those of many recently isolated hospital strains. In this study, we show that the major outer membrane proteins of the latter strains, in spite of considerable heterogeneity of their patterns on gels, resemble those of E. coli $\mathrm{K} 12$ in several biochemical and immunological properties.

\section{METHODS}

Strains and growth conditions. The multi-auxotrophic E. coli K12 strain PC0479 (Verhoef et al., 1979) was used as a reference. The $45 \mathrm{E}$. coli strains used were isolated from human faeces, blood and urine. They were obtained from W. C. van Dijk and J. Verhoef, Department of Microbiology, State University, Utrecht, The Netherlands. Their relevant properties are listed in Table 1. Cells were grown in yeast broth (Lugtenberg et al., 1976) at $37^{\circ} \mathrm{C}$ under vigorous aeration to the late exponential phase, harvested at $4{ }^{\circ} \mathrm{C}$ and washed with $0.9 \%(\mathrm{w} / \mathrm{v}) \mathrm{NaCl}$.

Isolation and characterization of membrane fractions. Cell envelopes were prepared by differential centrifugation after disruption of the cells by ultrasonic treatment (Lugtenberg et al., 1975). A fraction containing the outer membrane proteins was isolated from cell envelopes by a slight modification (Lugtenberg et al., 1976) of the Triton X-100 extraction procedure described by Schnaitman (1974). A fraction containing proteins tightly associated with the peptidoglycan was prepared by incubation of cell envelopes at $60^{\circ} \mathrm{C}$ in the presence of $2 \%$ SDS followed by ultracentrifugation (Lugtenberg et al., 1977). Trypsin-treated cell envelopes were prepared by incubation of cell envelopes (300 to $400 \mu \mathrm{g}$ protein) in $25 \mathrm{~mm}$-Tris/ $\mathrm{HCl}$ buffer $\mathrm{pH} 7 \cdot 2$ containing $50 \mu \mathrm{g}$ trypsin $\mathrm{ml}^{-1}$, in a final volume of $100 \mu \mathrm{l}$. After incubation for $1 \mathrm{~h}$ at $37^{\circ} \mathrm{C}$, the mixture was chilled in ice-water, then $100 \mu \mathrm{l}$ buffer ( $50 \mathrm{~mm}-\mathrm{Tris} / \mathrm{HCl} \mathrm{pH} 8.5$ containing $2 \mathrm{~mm}$-EDTA and $0.2 \mathrm{M}-\mathrm{KCl}$ ) was added, and cell envelopes were harvested by centrifugation for $15 \mathrm{~min}$ at $4{ }^{\circ} \mathrm{C}$ in an Eppendorf table centrifuge and washed once with $50 \mathrm{~mm}-\mathrm{Tris} / \mathrm{HCl} \mathrm{pH} \mathrm{7.2}$. Procedures used for the purification of heat unmodified, biologically active ompA protein (Van Alphen et al., 1977), SDS and heat modified $o m p C$ and $o m p F$ protein (Verhoef et al., 1979) and for lipopolysaccharide (LPS) (Galanos et al., 1969) have been described previously. These purified proteins were used as the antigens. Unless otherwise indicated, the protein patterns of membrane fractions were analysed using the SDS-polyacrylamide gel electrophoresis system described by Lugtenberg et al. (1975). In some cases $4 \mathrm{M}$-urea was added to the running gel in order to obtain a different resolution (M. Achtman, personal communication).

Preparation of antisera. Antisera against the purified ompA, ompC and ompF proteins were raised in rabbits by $\mathrm{H}$. Hofstra, Laboratory for Medical Microbiology, University Hospital, Groningen, The Netherlands, as described by Hofstra \& Dankert (1980). Briefly, after purification of the proteins as described, $5 \mathrm{mg}$ proteins was suspended in $0.5 \mathrm{ml} 0.9 \% \mathrm{NaCl}$ and mixed with the same volume of Freund's complete adjuvant. The antigens were administered in the upper hindleg region. After 4 weeks this injection was repeated, and blood was collected 7 weeks after the first injection. As the antisera contained activity against LPS in a haemagglutination assay, using sheep red blood cells coated with purified LPS, the antisera were absorbed by two successive incubations of $0.9 \mathrm{ml}$ serum with $0.1 \mathrm{ml}$ of a sonically treated suspension of purified $E$. coli $\mathrm{K} 12$ lipopolysaccharide $\left(10 \mathrm{mg} \mathrm{ml}^{-1}\right.$ in 10 mM-sodium phosphate buffer $\mathrm{pH} 7 \cdot 2$ containing $0.9 \% \mathrm{NaCl}$ ) and the precipitates were removed by centrifugation. After this treatment anti-LPS activity was undetectable.

Iodination of Protein A. Protein A of Staphylococcus aureus (Pharmacia, Uppsala, Sweden) was labelled with ${ }^{125}$ I (The Radiochemical Centre, Amersham) using chloramine T (Hunter \& Greenwood, 1962) by a modified method described by Erlich et al. (1978). 
Table 1. Escherichia coli strains of human origin

\begin{tabular}{cllclll} 
Strain* & \multicolumn{2}{l}{ Serotype } & & Strain* & \multicolumn{2}{c}{ Serotype† } \\
F1 & O78 & K- & S12 & O2 & K1 \\
F2 & O15 & K? & S13 & O18 & K1 \\
F3 & O41 & & S14 & O14 & K- \\
F4 & O88 & & S15 & O4 & K? \\
F5 & O1 & K1 & S16 & O78 & K80 \\
F6 & O77 & K96 & S17 & O106 & \\
F7 & NT & & S18 & O15 & K? \\
F8 & O156 & & S20 & O23 & K18 \\
F9 & O127 & K63 & U3 & O6 & K53 \\
F10 & NT & & U4 & O134 & \\
F11 & NT & & U6 & NT & \\
F12 & O2 & K? & U7 & O1 & K1 \\
S1 & O75 & K? & U8 & O40 & \\
S2 & O7 & K? & U11 & NT & \\
S3 & O18 & K? & U13 & AA & \\
S4 & O77 & K96 & U14 & O18 & K? \\
S5 & O51 & & U15 & AA & \\
S6 & O5 & K? & U16 & O18 & K1 \\
S7 & O78 & K80 & U17 & AA & \\
S8 & O4 & K12 & U18 & O71 & \\
S9 & O6 & K- & U19 & O9 & K? \\
S10 & O75 & K- & U20 & O15 & K? \\
S11 & O22 & K24 & & &
\end{tabular}

* $\mathrm{F}$ denotes strains isolated from faeces of healthy volunteers; $\mathrm{S}$ denotes strains isolated from blood cultures of patients with $E$. coli bacteraemia; $U$ denotes strains isolated from patients with urinary tract infection. All strains were isolated in the Netherlands.

† Serotyping was performed by Dr P. A. M. Guinée, National Institute for Public Health, Bilthoven, The Netherlands, using tube agglutination. Abbreviations: $\mathrm{K}-$, no $\mathrm{K}$ antigen detected using all $\mathrm{K}$ antisera; $\mathrm{K}$ ?, strains did not react in any of the $\mathrm{K}$ antisera nor in their homologous $\mathrm{O}$ antiserum in the living state; $\mathrm{NT}$, not typeable; AA, autoagglutinable.

Gel immuno-radioassay (GIRA). The procedure according to J. T. Poolman and others (personal communication) was slightly modified. The proteins of Triton $\mathrm{X}-100 / \mathrm{MgCl}_{2}$-extracted cell envelopes were separated by SDS-polyacrylamide gel electrophoresis as described previously (Lugtenberg et al., 1975), except that the gels were $3 \mathrm{~mm}$ thick and electrophoresis was carried out at $50 \mathrm{~mA}$ for $2.5 \mathrm{~h}$. Subsequently $4.5 \times 5 \mathrm{~cm}$ pieces, containing the region with the major membrane proteins, were cut out and immediately frozen at $-70^{\circ} \mathrm{C}$. These pieces were sliced into $50 \mu \mathrm{m}$ thin longitudinal sections at $-30^{\circ} \mathrm{C}$ using a cryostat microtome (Bright 5030). The gel slices were further handled as described in detail by Raamsdonk et al. (1977). After removal of SDS, the gel slices, spread on $8 \times 8 \mathrm{~cm}$ glass slides, were incubated with $350 \mu \mathrm{l}$ of an appropriate dilution (usually 1:250) of antiserum for $30 \mathrm{~min}$ at $37^{\circ} \mathrm{C}$, followed by incubation for $16 \mathrm{~h}$ at $4^{\circ} \mathrm{C}$. After floating the gel slices from the glass slides, they were transferred to Petri dishes and washed three to five times for $1 \mathrm{~h}$ with $10 \mathrm{mM}$-potassium phosphate buffer $\mathrm{pH} 7.2$ containing $0.9 \% \mathrm{NaCl}$, in order to remove excess and non-specifically bound IgG. The gel slices were again spread on the glass slides and ${ }^{125}$ I-labelled Protein A was allowed to bind to IgG by incubating each slice for $2 \mathrm{~h}$ at room temperature with $350 \mu \mathrm{l}$ of a solution containing ${ }^{125}$ I-labelled Protein A at $3 \mu \mathrm{Ci} \mathrm{ml}^{-1}\left(110 \mathrm{kBq} \mathrm{ml}^{-1}\right)$. After intensive washing, the gel slices were spread on the glass slides again and dried. Membrane proteins with attached IgG were detected by exposing the slice for 40 to $60 \mathrm{~h}$ to Fuji X-ray film. To check for non-specific adsorption of $\mathrm{IgG}$, control slices were incubated with normal rabbit serum.

\section{RESULTS}

\section{Major outer membrane protein patterns}

The pattern of the major outer membrane proteins of $E$. coli $\mathrm{K} 12$ was compared with those of recently isolated strains from various human sources (see Table 1). Preparations containing the outer membrane proteins, but not those of the cytoplasmic membrane, were obtained as a Triton $\mathrm{X}-100 / \mathrm{MgCl}_{2}$-insoluble cell envelope fraction. Such a preparation 


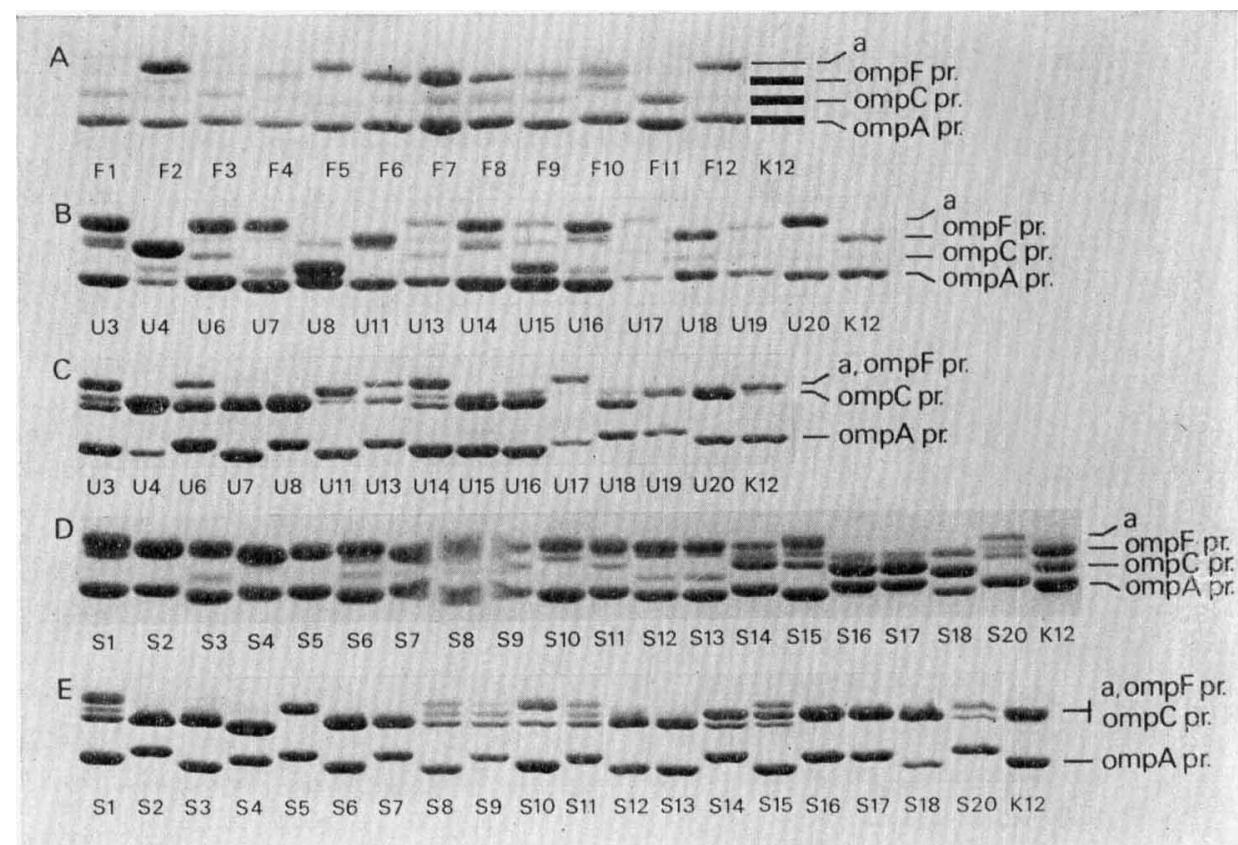

Fig. 1. SDS-polyacrylamide gel electrophoresis of outer membrane proteins of $F$ strains (A), $\mathbf{U}$ strains $(B, C)$ and $S$ strains $(D, E)$ in the absence $(A, B, D)$ or presence $(C, E)$ of 4 M-urea in the running gel. Only the relevant part of the gel, containing the major outer membrane proteins, is shown.

contained all major proteins present in the cell envelope (not shown). Preliminary experiments showed that of several SDS-polyacrylamide gel electrophoresis systems tested, the best resolution, with respect to the number of major protein bands, was obtained with the two systems described previously. The patterns obtained for the major outer membrane proteins with apparent molecular weights between about 30000 and 42000 are shown in Fig. 1. The results show that the patterns from the strains from faeces (F) (Fig. 1A), urine (U) (Fig. 1 B, C) and blood (S) (Fig. 1D, E) are all different from that of E. coli K12. In a number of cases a better resolution was obtained by including $4 \mathrm{M}$-urea in the running gel, as can be observed for strains U3, U11 and U14 by comparing Fig. 1(B) and 1(C) and for strains S1, S2, S4, S8, S9 and S11 by comparing Fig. 1(D) and 1(E). Based on the number of major protein bands, which ranged from two to five, and on their electrophoretic mobilities, 36 different patterns were observed among the 45 strains tested (Fig. 1). Attempts to correlate a certain type of protein pattern with a certain serotype for the $\mathrm{O}$ and/or $\mathrm{K}$ antigens, and vice versa, revealed that, except for the five strains with a $\mathrm{K} 1$ antigen, such a tight correlation did not appear to exist. The five $\mathrm{K} 1$ strains used in this study came from different sources (Table 1) and had indistinguishable protein patterns (strains F5, S12, S13, U7 and U16, see Fig. 1). However, examination of the outer membrane proteins of a larger number of $\mathrm{K} 1$ strains revealed that different patterns can also be observed among strains of this $\mathrm{K}$ serotype (L. Van Alphen, personal communication).

\section{Biochemical characterization of major outer membrane proteins}

The $\operatorname{mpA}$ protein of strain $\mathrm{K} 12$ is unique in that it is the only major outer membrane protein which is degraded during incubation of cell envelopes with trypsin, leaving a large degradation product with a molecular weight of about 18000 associated with the cell envelope (Henning et al., 1973). The known porins of $E$. coli $\mathrm{K} 12$ are the only proteins 

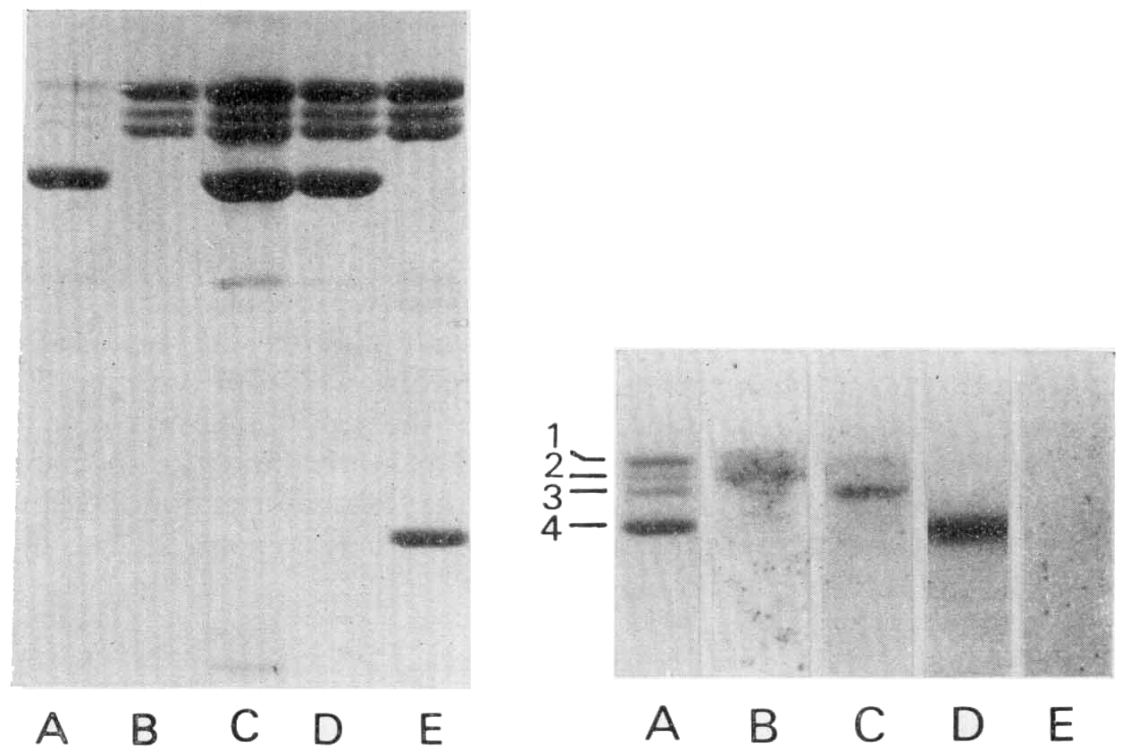

Fig. 2. SDS-polyacrylamide gel electrophoresis of membrane fractions of strain U13. With the cell envelope preparation (C) as the starting material, the following fractions were obtained: Triton $\mathrm{X}-100 / \mathrm{MgCl}_{2}$-insoluble material, containing the outer membrane proteins (D), a soluble (A) and an insoluble (B) fraction obtained after extraction in $2 \% \mathrm{SDS}$ at $60^{\circ} \mathrm{C}$, and a cell envelope sample treated with trypsin (E).

Fig. 3. SDS-polyacrylamide gel electrophoresis of outer membrane proteins of strain U13 on a $3 \mathrm{~mm}$ thick gel. After slicing, one section was stained (A), whereas others were incubated with anti-ompF protein serum (B), anti-omp $C$ protein serum (C), anti-omp $A$ protein serum (D) and normal rabbit serum (E) according to the GIRA technique (see Methods).

that remain attached to the peptidoglycan during extraction of cell envelopes with $2 \%$ SDS at $60^{\circ} \mathrm{C}$ (Lugtenberg et al., 1976). The outer membrane proteins of the recently isolated $E$. coli strains were tested for these properties in an attempt to correlate their protein patterns with that of strain K12. The results, which were similar for all strains (for an example, see Fig. 2), can be summarized as follows. For all strains the fastest moving band (in both gel systems) is the only major protein that is soluble in $2 \% \mathrm{SDS}$ at $60^{\circ} \mathrm{C}$ (Fig. 2A) and degraded by trypsin (Fig. 2E). After the latter treatment a new major band appeared with an apparent molecular weight of about 18000. A similar situation was observed in $E$. coli $\mathrm{K} 12$ where the new protein is known to be a degradation product of the ompA protein (Lugtenberg et al., 1976). Additional evidence for the notion that the new protein generated by trypsin treatment is a degradation product of the fastest moving major protein came from the observation that the differences in the electrophoretic mobility of this protein among the various strains (Fig. 1 C, E) were mimicked by the pattern of the protein bands which were generated by trypsin (results not shown). Except for the fastest moving protein, all other major proteins of all $\mathrm{F}, \mathrm{S}$ and $\mathrm{U}$ strains, present in one to four bands, shared the properties that they were resistant to trypsin treatment (Fig. 2E) and tightly associated with peptidoglycan (Fig. 2B). In these respects they behave like the known porins of strain K12 (Lugtenberg et al., 1976).

\section{Immunological characterization of major outer membrane proteins}

Although the biochemical properties tested have been well established for the $E$. coli $\mathrm{K} 12$ proteins, they are not very well understood. Therefore, we also tested the possible immunological relationships between the major outer membrane proteins of strain K12 and the 
new strains using the gel immuno-radioassay technique. This method is extremely sensitive and has the advantage that, as many slices can be cut from the same gel, the stained pattern of 10 to 12 strains can directly be compared with the patterns observed after reaction with the different antibody preparations (see Fig. 3). The results showed that, for all strains, antibodies against the purified $o m p A$ protein reacted specifically with the fastest moving band (Fig. 3D), whereas normal rabbit serum showed no reaction at all (Fig. 3E). These results indicate that the trypsin-sensitive proteins are immunologically related to the $o m p A$ protein of $E$. coli $\mathrm{K} 12$. The major peptidoglycan-associated proteins reacted with antibodies against the purified $o m p C$ and/or $o m p F$ proteins, while different degrees of affinity of the two antisera towards the various proteins were often observed. For example, Fig. 3 shows that the anti-ompF protein serum has more affinity for the peptidoglycan-associated proteins 1 and 2 (Fig. 3B), whereas anti-ompC protein serum has more affinity for the peptidoglycanassociated protein 3 (Fig. 3C). The results showed that all major peptidoglycan-associated proteins of all recently isolated strains have antigenic determinants in common with at least one of the $E$. coli $\mathrm{K} 12$ porins.

\section{DISCUSSION}

The patterns of major outer membrane proteins of $45 \mathrm{E}$. coli strains were investigated and compared with that of strain $\mathrm{K} 12$. The patterns of all recent isolates differed from that of strain K12. Surprisingly, the patterns of the former strains were extremely heterogeneous in that, based only on the electrophoretic mobilities of the major proteins, 36 different types were distinguished. The interpretation of these results could vary between the following extremes: (i) many E. coli strains basically differ from each other with respect to the structures of their major proteins; (ii) these proteins differ mainly from each other in apparent molecular weight due to evolutionary processes but proteins with very similar structures and functions are present in all strains. In order to distinguish between these two extremes, the outer membrane proteins were tested for several biochemical and immunological properties known for the major outer membrane proteins of strain K12. The results showed that in all recent isolates the major protein with the highest electrophoretic mobility behaved like the $o m p A$ protein of strain K12 (Fig. 2 and 3). All other major proteins were peptidoglycan-associated (Fig. 2 and text) ard react with anti-ompC protein serum and/or anti-omp $F$ protein serum (Fig. 3 and text).

It should be noted that recent results with $E$. coli $\mathrm{K} 12$ outer membrane proteins have shown that anti-ompA protein serum reacts only with the homologous protein whereas anti-ompC and anti-ompF protein sera react with both porins (Overbeeke et al., 1980). Thus, we conclude that all major outer membrane proteins of the recent isolates are closely related either to the $\operatorname{omp} A$ protein or to one or both of the porins of strain $\mathrm{K} 12$. Similar results were observed when the relationship between the major outer membrane proteins of E. coli $\mathrm{K} 12$ was compared with those of other Enterobacteriaceae (Hofstra \& Dankert, 1979; Overbeeke et al., 1980). Thus, all peptidoglycan-associated major outer membrane proteins of Enterobacteriaceae in the molecular weight range between 30000 and 42000 are structurally related with at least one of the K12 porins and therefore probably function as general pores.

Many of the strains tested are encapsulated (see Table 1). Recently, Paakkanen et al. (1979) reported the presence of a specific major outer membrane protein in encapsulated strains of $E$. coli with an apparent molecular weight in gradient gels of 40000 . With respect to its amino acid composition and amino terminus, this $\mathrm{K}$ protein is very similar to the porins of strain K12. Comparison of the outer membrane protein patterns of the strains used in the present study does not show the presence of a band common for all encapsulated strains (Fig. 1). The difference in electrophoretic mobilities of the $o m p A$-like proteins and of the porin-like proteins observed in the various strains even suggest that a protein with 
a certain function has been subject to different patterns of evolution in various strains, resulting in differences in electrophoretic mobilities. Although our results certainly do not exclude the existence of a $\mathrm{K}$ protein, they make it likely that such a protein would not have exactly the same electrophoretic mobility in all encapsulated strains.

We are grateful to Jan Poolman for his help with the GIRA technique, to Jan Verhoef and Willemien C. van Dijk for providing us with the strains, to P. A. M. Guinée for performing the serotyping of the strains, and to H. Hofstra for raising the antisera. The technical assistance of Ria van Boxtel and Joke Vernooy during part of this study was greatly appreciated.

\section{REFERENCES}

Ames, G. F., Spudich, E. N. \& NiKaido, H. (1974). Protein composition of the outer membrane of Salmonella typhimurium: effect of lipopolysaccharide mutations. Journal of Bacteriology 117, 406-416.

Bassford, P. J., Diedrich, D. L., Schnattman, C. A. \& ReEves, P. (1977). Outer membrane proteins of Escherichia coli. VI. Protein alteration in bacteriophage-resistant mutants. Journal of Bacteriology 131, 608-622.

Bavoll, P., NiKaido, H. \& von Meyenburg, K. (1977). Pleiotropic transport mutants of Escherichia coli lack porin, a major outer membrane protein. Molecular and General Genetics 158, 23-33.

Braun, V. \& Krieger-Brauer, H. J. (1977). Interrelationship of the phage $\lambda$ receptor protein and maltose transport in mutants of Escherichia coli K12. Biochimica et biophysica acta 469, 89-98.

Braun, V., Hancock, R. E. W., HantKe, K. \& HARTMANN, A. (1976). Functional organization of the outer membrane of Escherichia coli: phage uptake systems. Journal of Supramolecular Structure 5, 37-58.

Di Rienzo, J. M., Nakamura, K. \& Inouye, M. (1978). The outer membrane proteins of Gramnegative bacteria: biosynthesis, assembly and functions. Annual Review of Biochemistry 47, 481-532.

Erlich, H. A., Cohen, S. N. \& McDevvitt, H. O. (1978). A sensitive radioimmunoassay for detecting products translated from cloned DNAfragments. Cell 13, 681-689.

Galanos, C., Lüderitz, O. \& Westrhal, O. (1969). A new method for the extraction of $\mathrm{R}$ lipopolysaccharides. European Journal of Biochemistry 9, 245-249.

HenNing, U. \& Haller, I. (1975). Mutants of Escherichia coli $\mathrm{K} 12$, lacking all 'major' proteins of the outer cell envelope membrane. FEBS Letters 55, 161-164.

Henning, U., Rehn, K. \& Hoehn, B. (1973). Cell envelope and shape of Escherichia coli K12. Proceedings of the National Academy of Sciences of the United States of America 70, 2033-2036.

Henning, U., Schmidmayr, W. \& Hindennach, I. (1977). Major proteins of the outer cell envelope membrane of Escherichia coli K12: multiple species of protein I. Molecular and General Genetics 154, 293-298.
Hofstra, H. \& Dankert, J. (1979). Antigenic cross-reactivity of major outer membrane proteins in Enterobacteriaceae species. Journal of General Microbiology 111, 293-302.

Hofstra, H. \& DankerT, J. (1980). Preparation and quantitative determination of antibodies against major outer membrane proteins of Escherichia coli $\mathrm{O} 26 \mathrm{~K} 60$. Journal of General Microbiology 117, 437-447.

Hunter, W. M. \& Greenwood, F. (1962). Preparation of iodine-131 labelled human growth hormone of high specific activity. Nature, London 194, 495-496.

ICHIHARA, S. \& Mizushima, S. (1978). Characterization of major outer membrane proteins $\mathrm{O} 8$ and $\mathrm{O} 9$ of Escherichia coli K12. Evidence that structural genes for the two proteins are different. Journal of Biochemistry 83, 1095-1100.

Lugtenberg, B., Meijers, J., Peters, R., Van Der HoEk, P. \& VAN AlPhen, L. (1975). Electrophoretic resolution of the major outer membrane protein of Escherichia coli $\mathrm{K} 12$ into four bands. FEBS Letters 58, 254-258.

Lugtenberg, B., Peters, R., Bernheimer, H. \& BerEndSEN, W. (1976). Influence of cultural conditions and mutations on the composition of the outer membrane proteins of Escherichia coli. Molecular and General Genetics 147, 251-262.

Lugtenberg, B., Bronstein, H., Van Selm, N. \& PETERS, R. (1977). Peptidoglycan-associated outer membrane proteins in Gram-negative bacteria. Biochimica et biophysica acta 465, 571-578.

LutKenhaus, J. F. (1977). Role of a major outer membrane protein in Escherichia coli. Journal of Bacteriology 131, 631-637.

NAKAE, T. (1976). Identification of the outer membrane of Escherichia coli that produces transmembrane channels in reconstituted vesicle membranes. Biochemical and Biophysical Research Communications 71, 877-884.

OVERBEeke, N. \& Lugtenberg, B. (1980). Expression of outer membrane protein e of Escherichia coli K12 by phosphate limitation. FEBS Letters 112, 229-232.

OverbeEke, N., VAN ScharrenburG, G. \& LUGTENBERG, B. (1980). Antigenic relationship between pore proteins of Escherichia coli K12. European Journal of Biochemistry 110, 247-254.

Paakkanen, J., Gotschlich, E. C. \& Mäkelä, P. H. (1979). Protein K: a new major outer membrane 
protein found in encapsulated Escherichia coli. Journal of Bacteriology 139, 835-841.

RaAmsdonk, W. van, Pool, C. W. \& Heyting, C. (1977). Detection of antigens and antibodies by an immuno-peroxidase method applied on thin longitudinal sections of SDS polyacrylamide gels. Journal of Immunological Methods 17, 337-348.

Reeves, P. (1979). The genetics of outer membrane proteins. In Bacterial Membranes: Biogenesis and Functions, pp. 255-291. Edited by M. Inouye. New York: Wiley-Interscience.

Rosenbusch, J. P. (1974). Characterization of the major envelope protein from Escherichia coli. Regular arrangement on the peptidoglycan and unusual dodecyl sulfate binding. Journal of Biological Chemistry 249, 8019-8029.

SCHNAITMAN, C. (1974). Outer membrane proteins of Escherichia coli. Evidence that the major protein of Escherichia coli $\mathrm{O} 111$ outer membrane consists of four distinct polypeptide species. Journal of Bacteriology 118, 442-453.

Skurray, R. A., Hancock, R. E. W. \& Reeves, P. (1974). Con ${ }^{-}$mutants: class of mutants in Escherichia coli K12 lacking a major cell wall protein and defective in conjugation and adsorption of a bacteriophage. Journal of Bacteriology 119, 726-735.

UEMURA, J. \& MizUSHIMA, S. (1975). Isolation of outer membrane proteins of Escherichia coli and their characterization on polyacrylamide gel. Biochimica et biophysica acta 413, 163-176.

VAN Alphen, W. \& Lugtenberg, B. (1977). Influence of osmolarity of the growth medium on the outer membrane pattern of Escherichia coli. Journal of Bacteriology 131, 623-630.

Van Alphen, L., Havekes, L. \& Lugtenberg, B. (1977). Major outer membrane protein d of Escherichia coli K12. Purification and in vitro activity of bacteriophage $\mathrm{K} 3$ and $\mathrm{F}$-pilus mediated conjugation. FEBS Letters 75, 285-290.

Van Alphen, W., Van Boxtel, R., Van Selm, N. \& Lugtenberg, B. $(1978 a)$. Pores in the outer membrane of Escherichia coli K12. Involvement of proteins $\mathrm{b}$ and $\mathrm{c}$ in the permeation of cephaloridine and ampicillin. FEMS Microbiology Letters 3, 103-106.

Van Alphen, W., Van Selm, N. \& Lugtenberg, B. $(1978 b)$. Pores in the outer membrane of Escherichia coli $\mathrm{K} 12$. Involvement of proteins $\mathrm{b}$ and $\mathrm{e}$ in the functioning of pores for nucleotides. Molecular and General Genetics 159, 75-83.

Verhoef, C., LugtenberG, B., VAN Boxtel, R., De GraafF, P. \& VerheiJ, H. (1979). Genetics and biochemistry of the peptidoglycan-associated proteins b and c of Escherichia coli K12. Molecular and General Genetics 169, 137-146. 